\title{
TEKANAN EKONOMI, STRATEGI KOPING, DAN KETAHANAN KELUARGA YANG MENIKAH USIA MUDA
}

\author{
Tin Herawati ${ }^{1 *}$, Fatma Putri Sekaring Tyas ${ }^{1}$, Lely Trijayanti $^{1}$ \\ ${ }^{1}$ Departemen IImu Keluarga dan Konsumen, Fakultas Ekologi Manusia, Institut Pertanian Bogor, Bogor 16680, \\ Indonesia
}

*)E-mail: gmsk29@yahoo.com

\begin{abstract}
Abstrak
Keluarga menikah usia muda adalah susunan orang-orang yang disatukan oleh ikatan perkawinan darah atau adopsi, terdiri dari suami, istri, dan anak-anak serta anggota keluarga lainnya yang mana suami atau istri tersebut menikah di bawah usia 20 tahun. Tujuan penelitian ini adalah untuk menganalisis pengaruh tekanan ekonomi dan strategi koping terhadap ketahanan keluarga yang suami atau istri atau keduanya berusia di bawah 20 tahun ketika menikah. Penelitian dilakukan di Desa Cihideung Udik dan Desa Tegal Waru, Kecamatan Ciampea, Kabupaten Bogor. Contoh penelitian adalah keluarga yang suami atau istri atau keduanya menikah di bawah usia 20 tahun dan memiliki anak usia 0-6 tahuPn. Penelitian ini melibatkan 70 responden ibu dari keluarga contoh. Hasil penelitian menunjukkan bahwa tekanan ekonomi keluarga termasuk kategori sedang, strategi koping keluarga tergolong kategori rendah, dan ketahanan keluarga tergolong sedang. Faktor yang memengaruhi ketahanan keluarga adalah jumlah anggota keluarga, lama menikah, dan tekanan ekonomi. Sementara itu, jumlah anggota keluarga dan lama menikah berpengaruh positif signifikan terhadap ketahanan keluarga dan tekanan ekonomi berpengaruh negatif signifikan terhadap ketahanan keluarga. Penelitian selanjutnya diharapkan melibatkan suami sebagai responden dan melibatka lebih banyak variabel untuk menjelaskan secara empiris kehidupan keluarga menikah usia muda seperti manajemen sumber daya keluarga, penyesuaian keluarga, keintiman dari pasangan suami istri, dan perkembangan anak dari pasangan muda.
\end{abstract}

Kata kunci: keluarga menikah usia muda, ketahanan keluarga, strategi koping, tekanan ekonomi

\section{Economic Pressure, Coping Strategy, and Family Strength in Early Marriage Family}

\begin{abstract}
Early marriage family refer to united people by blood or adoption, consisting of husband, wife, children and other family members in which one of husband or wife or both of them are married under 20 years old. The purpose of this study was to analyze the correlation and the influence of economic pressure and coping strategy on family strength among early marriage family. The study was conducted in the Cihideung Udik village and Tegal Waru village, Ciampea Sub District, Bogor Distr. The samples of this research were families who the husband or wife or both were under 20 years old when they were married and had children who aged 0-6 years old. There were 70 mothers of sample families as respondents. This research showed that the family economic pressures were in the the medium category, family coping strategies were in the low category, and family strength were in the medium category. Family strength affected by length of marriage, number of family member, and economic pressure. Moreover, the number of family members and length of marriage had a significant positive influence on family strength. On the other hand, economic pressures had a significant negative influence on family strength. Further research is expected to involve husband in interviews and to involve some variables that can give a comprehensive empirical evidence to explore the life of early marriage family; such as family resource management, family adjustment, intimacy of married couples, and child development of young couples.
\end{abstract}

Keywords: coping strategy, early marriage family, economic pressure, family strength

\section{PENDAHULUAN}

Salah satu faktor yang menentukan keharmonisan keluarga adalah ketahanan keluarga, termasuk pada keluarga menikah usia muda. Ketahanan keluarga merupakan kemampuan keluarga dalam mengelola sumber daya yang dimiliki dan menanggulangi masalah yang dihadapi, untuk memenuhi kebutuhan fisik dan psikososial keluarga. Variasi keluarga dalam melaksanakan fungsi, mengelola sumber daya yang dimiliki, dan kemampuan keluarga mengelola masalah serta stres yang dihadapi menyebabkan ketahanan keluarga menjadi faktor yang penting diperhatikan (Hartoyo, 2009). Menurut Sunarti (2001) ketahanan keluarga akan tercapai apabila keluarga terhindar dari 
permasalahan ekonomi dan masalah non ekonomi. Herawati (2012) menyatakan bahwa adanya masalah ekonomi yang dialami keluarga, akan menyebabkan keluarga tidak mampu memenuhi kebutuhan keluarga sehingga dapat menurunkan ketahanan keluarga. Sunarti (2001) membagi ketahanan keluarga menjadi tiga, yaitu ketahanan fisik, ketahanan sosial, dan ketahanan psikologis. Ketahanan fisik keluarga didefinisikan sebagai kemampuan ekonomi yang dimiliki oleh keluarga yaitu komponen anggota keluarga dalam memperoleh sumber daya ekonomi dari luar sistem untuk memenuhi kebutuhan dasar seperti pangan, sandang, papan, pendidikan, dan kesehatan. Sementara itu, ketahanan sosial keluarga merupakan ketahanan keluarga dalam menerapkan nilai agama, memelihara mekanisme penanggulangan krisis yang baik pula. Selanjutnya ketahanan psikologis keluarga adalah kemampuan anggota keluarga dalam mengelola emosi, sehingga menghasilkan konsep diri yang positif (Sunarti, 2001).

Strategi koping erat kaitnya dengan ketahanan keluarga. Koping didefinisikan sebagai perubahan kognitif seseorang secara konstan dan usaha nyata berupa perilaku untuk mengatur permintaan yang berasal dari dalam diri maupun yang berasal dari luar diri yang dinilai melebihi kemampuan atau kapasitas sumber daya yang dimiliki oleh individu tersebut (Lazarus \& Folkman, 1984). Strategi koping merupakan suatu bentuk upaya yang dilakukan oleh keluarga untuk mencapai tingkat keseimbangan serta bentuk penyesuaian terhadap krisis yang dihadapi oleh keluarga (Herawati, 2012). Strategi koping dapat dilakukan dengan mengalokasikan sumber daya dan memberdayakan kemampuan anggota keluarganya (Herawati, 2012). Apabila keluarga dapat memberdayakan anggota keluarganya maka ketahanan keluarga dapat dicapai secara optimal. Perbedaan sumber daya yang dimiliki keluarga mengakibatkan perbedaan kemampuan pada keluarga untuk melakukan strategi koping.

Puspitawati (2012) menyatakan salah satu upaya strategi koping keluarga untuk mengatasi masalah ekonomi adalah melalui strategi peningkatan pendapatan, yaitu strategi yang diarahkan untuk meningkatkan sumber daya keuangan keluarga anggota keluarga mencari dan melakukan kerja tambahan, menambah waktu bekerja yang lebih lama, ataupun menambah anggota keluarga yang bekerja. Selain itu, ada juga strategi pengurangan pengeluaran, yaitu keluarga melakukan penghematan terhadap kebutuhan hidup. Bahkan strategi koping pengurangan pengeluaran dinilai lebih mudah dilakukan keluarga dibandingkan strategi penambahan pendapatan. Rosidah et al. (2012) menyatakan strategi peningkatan penambahan membutuhkan sumber daya manusia dan jejaring sosial untuk meningkatkan sumber daya uang. Tingginya penerapan strategi koping ekonomi menunjukkan tingginya tingkat tekanan yang dialami keluarga (Firdaus \& Sunarti, 2009).

Pernikahan usia muda merupakan gambaran rendahnya kualitas kependudukan dan menjadi fenomena di masyarakat. Pernikahan muda berdampak pada ketahanan keluarga yang akan berujung pada kesejahteraan keluarga. Dampak yang sangat mungkin terjadi adalah tekanan ekonomi keluarga sehingga dibutuhkan strategi koping keluarga agar keluarga tahan dalam mengatasi permasalahan yang ada. Tekanan ekonomi yang terjadi secara terus-menerus akan meningkatkan kadar kemarahan individu, permusuhan, depresi, kecemasan, kesehatan fisik, dan menurunkan kualitas hubungan (Fox \& Bartholomae, 2000). Tekanan ekonomi merupakan suatu kondisi sebuah keluarga tidak mampu memenuhi kebutuhan dasar seperti sandang, pangan, dan papan serta kebutuhan lainnya seperti rekreasi bersama keluarga (Mistry et al., 2008). Dew (2008) menyatakan bahwa pasangan baru menikah pada umumnya memiliki hutang. Tekanan ekonomi akan memicu kekerasan, terutama pada pria dan mengurangi kehangatan emosional dalam pernikahan sehingga akan berkontribusi terhadap berkurangnya stabilitas dan kepuasan pernikahan. Pasangan yang baru menikah di wilayah perdesaan memiliki pendapatan yang lebih rendah, selain itu pasangan baru menikah juga memiliki tingkat pendidikan yang lebih rendah yang akan berkontribusi pada sulitnya mendapat pekerjaan yang layak (Higginbotham \& Felix, 2009). Kesulitan ekonomi yang dialami membutuhkan dukungan sosial sebagai koping dan sumber daya tambahan (Henly et al., 2003). Hal ini membuat keluarga menikah muda yang mengalami tekanan ekonomi harus memiliki strategi koping untuk mengatasi permasalahan yang dihadapi keluarga untuk mencapai ketahanan keluarga.

Usia menikah merupakan salah satu faktor yang harus dipersiapkan sebelum menikah. Ghalili et al., (2012) menyatakan semakin tinggi usia menikah maka semakin tinggi 
tingkat pendidikan sehingga dapat mempersiapkan pernikahannya dengan baik. Indonesia termasuk negara dengan presentase pernikahan usia muda tinggi di dunia yakni menduduki rangking ke 37 dan tertinggi kedua ASEAN setelah Kamboja (BKKBN, 2012). Pernikahan diusia muda menjadi salah satu budaya di Indonesia. Beberapa masyarakat masih memiliki anggapan bahwa seorang anak perempuan harus segera dinikahkan setelah mengalami pubertas, apabila tidak melakukannya akan dianggap tabu dan memalukan keluarganya. Anggapan tersebut menyebabkan pernikahan menjadi salah satu cara untuk mendapatkan status sosial di dalam suatu kelompok masyarakat (Sudarto, 2014). Pemerintah melalui Badan Kependudukan dan Keluarga Berencana Nasional (BKKBN) membuat Program Pendewasaan Usia Perkawinan (PUP) dalam rangka memberikan pengertian dan pemahaman serta kesadaran kepada remaja dalam merencanakan keluarga dengan mempertimbangkan berbagai aspek untuk meminimalisir perceraian. PUP adalah upaya untuk meningkatkan usia minimal pada pernikahan pertama sehingga mencapai usia minimal 20 tahun bagi perempuan dan 25 tahun bagi laki-laki (BKKBN, 2010).

Pernikahan muda berhubungan dengan rendahnya pendidikan dan status ekonomi keluarga (Jain et al., 2011; Sah et al., 2014; Jisun, 2016). Faktor yang menjadi pendorong seseorang menikah usia muda adalah faktor ekonomi dan kemiskinan (Rafidah et al., 2009). BKKBN (2012) menyatakan penyebab pernikahan muda diantaranya status ekonomi, pendidikan yang rendah, budaya nikah muda, pernikahan yang dipaksa, dan seks bebas. Data BPS (2012) menemukan Kabupaten Bogor mempunyai jumlah penduduk miskin lebih tinggi dibandingkan Kota Bogor yaitu sebesar 10,8 persen dan 8,8 persen pada Kota Bogor. Berdasarkan data tersebut maka peluang terlaksananya menikah muda lebih tinggi di perdesaan dibanding di perkotaan. Selanjutnya Landung et al. (2009) pernikahan muda biasanya terjadi di masyarakat pedesaan dan biasanya hal ini terjadi pada golongan ekonomi menengah bawah. Pasangan yang hidup di perdesaan menghadapi hal-hal tekanan ekonomi yang berimplikasi pada outcome pernikahan, termasuk ketegangan ekonomi, rendahnya tingkat pendidikan, besarnya jumlah anggota keluarga, dan rendahnya pendapatan suami (Higginbotham \& Felix, 2009). Ahmed et al. (2013) menyatakan bahwa menikah diusia muda akan meningkatkan stres dan tekanan sehingga akan menimbulkan banyak permasalahan.

Beberapa penelitian menyatakan bahwa ketidakstabilan pernikahan dapat ditemukan pada masa sebelum pernikahan dan pada masa awal pernikahan. Ketidakstabilan dalam pernikahan muda ini yang dapat menyebabkan terjadinya perceraian. Duvall (1971) menyatakan kecenderungan untuk melakukan perceraian meningkat pesat setelah bulanbulan pertama pernikahan hingga mencapai puncak pada saat mendekati tahun pertama. Angka perceraian di Kabupaten Bogor lebih tinggi dibandingkan Kota Bogor, yaitu sebanyak 1.200 di Kabupaten Bogor dan 774 di Kota Bogor pada tahun 2011 (BPS, 2012). Sebagian masyarakat belum menyadari dampak yang terjadi apabila seseorang menikah usia muda. Penelitian terdahulu mengenai pernikahan usia muda lebih banyak mengkaji dampak menikah usia muda dibidang kependudukan terutama isu ekonomi. Oleh karena itu, masih diperlukan informasi dan pengetahuan untuk mengetahui tekanan ekonomi, strategi koping, dan ketahanan keluarga pada keluarga menikah diusia muda. Berdasarkan pemaparan tersebut penelitian ini bertujuan untuk: (1) mengidentifikasi karakteristik keluarga, tekanan ekonomi, strategi koping, dan ketahanan keluarga menikah diusia muda, dan (2) menganalisis pengaruh karakteristik keluarga, tekanan ekonomi, dan strategi koping terhadap ketahanan keluarga menikah diusia muda.

\section{METODE}

Penelitian ini menggunakan desain cross sectional study, yaitu penelitian dilakukan dengan meneliti pada satu waktu tertentu. Pemilihan tempat penelitian di pilih secara purposive, yaitu di Kabupaten Bogor dengan pertimbangan Kabupaten Bogor memiliki jumlah pernikahan yang lebih banyak dan memiliki tingkat kemiskinan yang lebih tinggi dibandingkan Kota Bogor.Selanjutnya dipilih Kecamatan Ciampea dengan pertimbangan memiliki jumlah pernikahan muda yang tinggi (Kementerian Agama, 2013).Lokasi penelitian di dua desa, yaitu Desa Tegal Waru dan Desa Cihideung Udik Kecamatan Ciampea. Waktu penelitian terdiri dari persiapan, pengumpulan data, pengolahan data, analisis data, dan penulisan laporan yang dilakukan dalam jangka waktu Oktober 2014 hingga Mei 2015.

Populasi penelitian ini adalah keluarga yang menikah usia muda di Kecamatan Ciampea. Contoh dalam penelitian ini adalah keluarga 
yang menikah usia muda dan memiliki anak usia 0-6 tahun. Responden dalam penelitian ini adalah ibu yang menikah usia muda dan memiliki anak usia 0-6 tahun. Teknik penarikan contoh menggunakan metode purposive sampling. Jumlah contoh yang diambil untuk penelitian ini sebanyak 70 orang. Sumber data dikumpulkan dari Kementerian Agama Kabupaten Bogor, Kantor Urusan Agama Kecamatan Ciampea, dan tokoh masyarakat di Desa Tegal Waru dan Desa Cihideung Udik.

Data yang dikumpulkan adalah data primer dan data sekunder. Pengumpulan data dilakukan melalui wawancara dengan menggunakan kuesioner meliputi: usia suamiistri, lama menikah, besar keluarga, lama pendidikan suami istri, pekerjaan suami istri, dan pendapatan per kapita. Usia suami-istri, usia menikah suami dan istri, lama menikah, jumlah anggota keluarga, lama pendidikan suami dan istri, pendapatan per kapita memiliki skala data rasio. Jenis pekerjaan suami dan istri memiliki skal nominal. Kuesioner tekanan ekonomi dikembangkan dari Conger \& Elder (1994) oleh Tati (2004) dengan nilai cronbach's alpha sebesar 0,810. Kuesioner terdiri dari 20 item pertanyaan. Pilihan jawaban variabel tekanan ekonomi menggunakan pilihan jawaban "tidak pernah", "kadangkadang" dan "sering".

Variabel strategi koping menggunakan kuesioner yang diacu dan dimodifikasi dari Puspitawati (2012) yang terdiri dari dimensi strategi koping pengurangan pengeluaran dan strategi koping peningkatan pendapatan. Masing-masing dimensi terdiri dari aspek pangan, kesehatan, pendidikan, dan aspek lainnya. Nilai Cronbach's alpha sebesar 0,656. Kuesioner terdiri dari 31 item pertanyaan. Pilihan jawaban variabel strategi koping, yaitu "tidak pernah", "kadang-kadang", dan "sering".Variabel ketahanan keluarga menggunakan kuesioner yang diacu dan dimodifikasi dari Sunarti (2001) dengan nilai Cronbach's alpha sebesar 0,734. Kuesioner terdiri dari 52 item pertanyaan. Variabel ketahanan keluarga terdiri dari dimensi ketahanan fisik, ketahanan sosial, dan ketahanan psikologis. Pilihan jawaban yang digunakan pada variabel ketahanan keluarga adalah "ya" dan "tidak".

Variabel penelitian selanjutnya diberikan skor penilaian pada setiap pertanyaannya di kuesioner. Variabel variabel tekanan ekonomi diberikan skor ( $0=$ tidak pernah), (1=kadangkadang), dan ( $2=$ sering). Variabel strategi koping diberikan skor (1=tidak pernah), (2=kadang-kadang), $\quad(3=$ sering $) . \quad$ Variabel ketahanan keluarga diberikan skor ( 0 =tidak) dan (1=ya). Kemudian skor total dari masingmasing variabel ditransformasikan menjadi indeks. Hal ini dilakukan agar memperoleh nilai minimum 0 dan nilai maksimum 100 dan untuk menyamakan satuan agar perbandingan pengkategorian data setiap variabel seragam (Puspitawati \&Herawati, 2013). Selanjutnya indeks dikategorikan menjadi tiga kategori, yaitu rendah $(0,00-33,33)$, sedang $(33,34$ $66,67)$, dan tinggi $(66,68-100,00)$. Data yang dikumpulkan melalui wawancara, kemudian diolah dan dianalisis melalui Microsoft Excel dan SPSS for windows. Proses pengolahan data meliputi editing, coding, entry, scoring, dan analisis. Data dianalisis menggunakan analisis deskriptif dan inferensia. Analisis deskriptif yang digunakan meliputi frekuensi distribusi, standar deviasi, nilai minimum, nilai maksimum, dan rata-rata. Analisis inferensia yang dilakukan meliputi uji regresi untuk menganalisis pengaruh karakteristik keluarga, tekanan ekonomi, strategi koping terhadap ketahanan keluarga pada keluarga menikah diusia muda.

Persamaan linear yang digunakan untuk uji regresi, yaitu:

$$
\begin{aligned}
& Y^{1}=\alpha+\beta^{1} X^{1}+\beta^{2} X^{2}+\beta^{3} X^{3}+\beta^{4} X^{4}+\beta^{5} \\
& X^{5}+\beta^{6} X^{6}+\beta^{7} X^{7}+\beta^{8} X^{8+} \beta^{9} X^{9} €
\end{aligned}
$$

Keterangan: $Y=$ ketahanan keluarga (indeks); $\alpha=$ konstanta regresi; $\quad \beta 1 \ldots \beta 9=$ koefisien $\quad$ regresi; X1=tekanan ekonomi (indeks); X2=strategi koping (indeks); X3=usia menikah istri (tahun); $X 4=$ usia menikah suami (tahun); X5=lama pendidikan suami (tahun); X6=lama pendidikan istri (tahun); X7=jumlah anggota keluarga (orang); X8=lama menikah (tahun); X9=pendapatan per kapita (Rp/Kapita/bulan); $€=$ galat

\section{HASIL}

\section{Karakteristik Keluarga}

Lama menikah pasangan suami istri berkisar 1 sampai 30 tahun dengan rata-rata lama menikah 11 tahun. Sebanyak 70,0 persen responden lama pernikahannya kurang dari 15 tahun dan sisanya 30,0 persen menikah lebih dari 15 tahun. Usia miminal menikah istri 13 tahun dan usia menikah suami 16 tahun. Ratarata usia suami ketika menikah adalah 22,1 tahun dan rata-rata ketika istri menikah adalah 17,3 tahun. Tingkat pendidikan yang telah dicapai lebih dari setengah istri $(60,0 \%)$ adalah tamat SD. Lama pendidikan yang ditempuh istri berkisar 3 sampai 12 tahun. Persentase tingkat pendidikan yang telah dicapai hampir setengah suami $(44,3 \%)$ adalah tamat SD. 
Lama pendidikan yang ditempuh suami berkisar 3 sampai 16 tahun. Rata-rata pendidikan istri dan suami 8 tahun atau berjenjang SMP.

Hasil penelitian menunjukkan tingkat pendidikan masih tergolong rendah dan belum menempuh pendidikan lebih dari sembilan tahun. Hasil penelitian menunjukkan lebih dari setengah suami $(55,7 \%)$ adalah buruh dan jenis pekerjaan lainnya adalah wiraswasta, swasta, guru, dan penjahit. Sebanyak 81,4 persen istri menjadi ibu rumah tangga dan lainnya bekerja sebagai wiraswasta, buruh, dan penjahit. Besar keluarga contoh antara 3 sampai 9 orang dengan rata-rata berjumlah anggota keluarga 4 orang. Sebagian besar keluarga contoh $(75,7 \%)$ termasuk dalam keluarga kecil. Pendapatan keluarga contoh perkapita perbulan berkisar antara Rp75.000,00 hingga Rp2.500.000 dan ratarata sebesar Rp594.696,00. Hasil penelitian menunjukkan setengah keluarga berada dalam kategori tidak miskin (51,4\%). Walaupun demikian ditemukan sebagian keluarga yang miskin $(20,0 \%)$ dan hampir miskin $(28,6 \%)$. Lebih dari setengah keluarga (52,9\%) mempunyai anak berusia 37 sampai 72 bulan dan sisanya $(47,1 \%)$ berusia 0 sampai 36 bulan.

\section{Tekanan Ekonomi}

Tekanan ekonomi keluarga diukur dengan kuesioner persepsi diri terhadap situasi dan keadaan ekonomi keluarga. Tabel 1 menunjukkan keluarga berada pada kategori tekanan ekonomi sedang, baik pada keluarga dengan lama menikah kurang dari sepuluh tahun $(48,5 \%)$ maupun keluarga dengan lama menikah lebih dari sepuluh tahun (62,2\%). Selanjutnya, hasil penelitian juga masih ditemukan tekanan ekonomi kategori tinggi pada 30,3 persen keluarga dengan lama menikah kurang dari sepuluh tahun dan keluarga dengan lama menikah lebih dari sepuluh tahun $(29,7 \%)$.

Tabel 1 Sebaran contoh berdasarkan kategori tekanan ekonomi keluarga

\begin{tabular}{lllll}
\hline \multirow{2}{*}{ Kategori } & \multicolumn{4}{l}{ Lama menikah } \\
Tekanan Ekonomi & $<10$ & Tahun & $\geq 10$ & Tahun \\
& $\mathrm{n}$ & $\%$ & $\mathrm{n}$ & $\%$ \\
\hline Rendah $(0,00-33,33)$ & 7 & 21,2 & 3 & 8,1 \\
Sedang $(33,34-66,67)$ & 16 & 48,5 & 23 & 62,2 \\
Tinggi $(66,68-100,00)$ & 10 & 30,3 & 11 & 29.7 \\
\hline Total & 33 & 100 & 37 & 100 \\
\hline Minimun-Maksimum & $17,5-90,0$ & $12,5-85,0$ \\
Rata-rata $\pm S D$ & $52,1 \pm 20,4$ & $56,9 \pm 16,1$ \\
\hline
\end{tabular}

Tekanan ekonomi kategori sedang dan tinggi ditunjukkan dengan sebagian besar responden merasa sering tidak puas dengan penghasilan keluarga, merasa penghasilan keluarga tidak mampu mencukupi kebutuhan keluarga, responden berfikir untuk bekerja untuk menambah pendapatan dan memenuhi kebutuhan, merasa perlu untuk mencari pekerjaan tambahan, merasa pengeluaran lebih besar dibandingkan pendapatan, merasa belum mampu untuk membeli rumah, merasa belum mampu memberikan rumah yang layak untuk keluarga, merasa perlu melakukan penghematan pengeluaran, merasa belum mampu membelikan mainan anak-anak, dan merasa tidak mampu mengajak anak-anak rekreasi dan liburan.

\section{Strategi Koping}

Strategi koping keluarga termasuk dalam kategori sedang baik pada keluarga dengan lama menikah kurang dari sepuluh tahun $(57,6 \%)$ maupun pada keluarga dengan lama menikah lebih dari sepuluh tahun $(56,8 \%)$ (Tabel 2). Strategi koping pengurangan pengeluaran kategori sedang baik pada keluarga dengan lama menikah kurang dari sepuluh tahun maupun dengan lama menikah lebih dari sepuluh tahun. Aspek pengurangan pengeluaran dibidang pangan tertinggi yaitu sering mengurangi konsumsi sumber pangan hewani (ayam, daging, ikan) dan merubah distribusi pangan. Aspek pengurangan pengeluaran dibidang kesehatan merupakan aspek tertinggi dari semua aspek strategi koping pengurangan pengeluaran. Keluarga sering mengganti obat yang mahal menjadi yang murah, memilih tempat berobat yang murah, dan menangguhkan pengobatan apabila ada keluarga yang sakit. Sebagian besar keluarga tidak melakukan strategi koping pengurangan pengeluaran untuk pendidikan. Selanjutnya lebih dari separuh keluarga contoh tidak pernah mengurangi penggunaan air/listrik/telepon.

Hasil penelitian juga menemukan bahwa hampir seluruh keluarga contoh melakukan strategi peningkatan pendapatan pada kategori rendah baik pada keluarga dengan lama menikah kurang dari sepuluh tahun maupun lebih dari sepuluh tahun. Sebagian besar keluarga tidak melakukan strategi peningkatan pendapatan baik pada aspek dibidang pangan, kesehatan, pendidikan, dan bidang lainnya. Meskipun demikian masih ditemukan persentasi tinggi di bidang lainnya, yaitu menjual aset untuk kebutuhan seharihari dan ibu ikut bekerja. 
Tabel 2 Sebaran contoh berdasarkan kategori strategi koping keluarga

\begin{tabular}{lllll}
\hline \multirow{2}{*}{ Kategori } & \multicolumn{4}{l}{ Lama menikah } \\
Strategi Koping & $<10$ Tahun & \multicolumn{2}{l}{$\geq 10$} & Tahun \\
& $\mathrm{n}$ & $\%$ & $\mathrm{n}$ & $\%$ \\
\hline Rendah $(0-33,33)$ & 14 & 42,4 & 15 & 40,5 \\
Sedang & 19 & 57,6 & 21 & 56,8 \\
$(33,34-66,67)$ & & & & \\
Tinggi $(66,68-100)$ & 0 & 0,0 & 1 & 2,7 \\
\hline Total & 33 & 100 & 37 & 100 \\
\hline Minimun-Maksimum & $14,5-59,6$ & $19,3-67,7$ \\
Rata-rata $\pm S D$ & $34,8 \pm 10,9$ & $39,5 \pm 13,5$ \\
\hline
\end{tabular}

\section{Ketahanan Keluarga}

Sebagian besar keluarga berada pada ketahanan keluarga dengan kategori sedang baik pada keluarga dengan lama menikah kurang dari sepuluh tahun $(84,8 \%)$ dan keluarga dengan lama menikah lebih dari sepuluh tahun $(83,8 \%)$ (Tabel 3). Ketahanan fisik keluarga berada pada kategori sedang disebabkan karena sebagian besar keluarga contoh memiliki rumah dan tanah sendiri (pada keluarga dengan lama menikah lebih dari sepuluh tahun), mampu menangani kesulitan ekonomi yang terjadi, anggota keluarga membantu ibu dalam melakukan pekerjaan rumah, keluarga besar membantu mengatasi kesulitan ekonomi yang terjadi, frekuensi makan utama dalam keluarga sebanyak 3 kali, ibu membantu tetangga yang mengalami kesulitan, ibu mampu memenuhi kebutuhan mainan yang mendukung perkembangan anak, keluarga tidak memiliki Askes, Askeskin, Jamkesmas, Jamkesda dan atau BPJS untuk biaya pengobatan, tetangga tidak membantu meringankan masalah ekonomi ibu, anggota keluarga tidak selalu makan lengkap sekali dalam sehari, dan keluarga tidak memiliki luas rumah lebih dari 7 meter persegi per orang.

Pada ketahanan sosial keluarga sebagian besar keluarga, keluarga memiliki cita-cita dan tujuan yang dicapai (keluarga dengan lama menikah lebih dari sepuluh tahun), anggota keluarga menerima dengan senang hati setiap tugas yang diterimanya, setiap anggota keluarga memiliki sikap saling menghargai satu sama lain, keluarga sering berkomunikasi setiap hari, keluarga sering berkomunikasi saat mau tidur, keluarga sering berkomunikasi waktu menonton televis, keluarga memiliki waktu khusus untuk berkumpul bersama setiap hari, ibu berinisiatif meminta nasihat kepada orang lain yang keluarga percaya, keluarga besar memberi nasihat mengenai masalah pernikahan, dan keluarga aktif dalam kegiatan sosial dilingkungan sekitar.
Tabel 3 Sebaran contoh berdasarkan kategori ketahanan keluarga

\begin{tabular}{lllll}
\hline \multirow{2}{*}{ Kategori } & \multicolumn{4}{l}{ Lama menikah } \\
Ketahanan Keluarga & $<10$ Tahun & $\geq 10$ & Tahun \\
& $\mathrm{n}$ & $\%$ & $\mathrm{n}$ & $\%$ \\
\hline Rendah (0-33,33) & 4 & 12,1 & 5 & 13,5 \\
Sedang $(33,34-66,67)$ & 28 & 84,8 & 31 & 83,8 \\
Tinggi $(66,68-100)$ & 1 & 3,0 & 1 & 2,7 \\
\hline Total & 33 & 100 & 37 & 100 \\
\hline Minimun-Maksimum & $23,0-69,23$ & $21,1-69,2$ \\
Rata-rata $\pm S D$ & $44,0 \pm 9,9$ & $42,8 \pm 11,5$ \\
\hline
\end{tabular}

Ketahanan psikologis keluarga, ibu memiliki konflik dengan suami dalam 6 bulan terakhir, ibu memiliki konflik dengan keluarga besar 6 bulan terakhir, ibu merasa kesulitan dalam mengasuh anak, ibu memiliki perasaan takut dicerai oleh suami, ibu sering merasa kesal pada diri sendiri karena merasa tidak berdaya, ibu memendam rasa bersalah dalam mengasuh anak, ibu memendam rasa marah kepada suami, ibu memendam rasa marah kepada keluarga besar, ibu merasa tidak puas dengan pendapatan keluarga saat ini, ibu merasa tidak puas dengan makanan yang di konsumsi setiap hari, ibu tidak merasa puas dengan pakaian yang dimiliki, dan ibu merasa tidak merasa puas dengan rumah yang ditempati, ibu tidak merasa telah menjadi istri yang baik, ibu tidak merasa telah menjadi orang tua yang baik, ibu tidak merasa telah menjadi tetangga yang baik, ibu selalu cemas dengan kehidupan masa depan, ibu tidak merasa telah menjadi insan beragama yang baik, dan suami tidak sering membantu untuk meringankan pekerjaan ibu.

\section{Pengaruh Karakteristik Keluarga, Tekanan Ekonomi, dan Strategi Koping Terhadap Ketahanan Keluarga}

Hasil uji regresi linear terhadap ketahanan keluarga menunjukkan bahwa hasil Adjusted $R^{2}$ sebesar 0,350 . Artinya sebanyak 35,0 persen ketahanan keluarga dipengaruhi oleh tekanan ekonomi dan strategi koping, sisanya sebesar 65,0 persen dipengaruhi oleh variabel lain di luar penelitian. Jumlah anggota keluarga $(\beta=4,877, \quad p=0,009)$ berpengaruh positif signifkan dengan ketahanan keluarga. Setiap kenaikan satu satuan jumlah anggota keluarga maka akan menaikkan ketahanan keluarga sebesar 4,877 poin. Lama menikah $(\beta=0,634$, $p=0,039$ ) berpengaruh positif yang signifikan terhadap ketahanan keluarga. Setiap kenaikan satu satuan lama menikah maka akan menaikan ketahanan keluarga sebesar 0,634 poin. Tekanan ekonomi $(\beta=-0,295, p=0,000)$ berpengaruh negatif signifikan terhadap ketahanan keluarga. Setiap kenaikan satu 
satuan tekanan ekonomi maka akan menurunkan ketahanan keluarga sebesar 0,295 poin.

\section{PEMBAHASAN}

Sebagian besar keluarga memiliki tingkat pendidikan yang rendah (tamat SD). Rafidah et al. (2009) pendidikan yang rendah berisiko 2,9 kali lebih besar menikah muda dibanding responden yang berpendidikan tinggi Tingkat pendidikan yang rendah akan berpengaruh terhadap jenis pekerjaan yang dimiliki. Yadollahi et al. (2009) menunjukkan bahwa tingkat pendidikan adalah salah satu determinan penting yang akan menentukan status ekonomi dan pekerjaan seseorang. Sebagian besar suami bekerja sebagai buruh, sedangkan sebagian besar istri bekerja sebagai ibu rumah tangga. Sebagian besar keluarga termasuk dalam keluarga kecil yang artinya keluarga memiliki tanggungan yang kecil dalam memenuhi kebutuhan sehari-hari. Menurut Firdaus dan Sunarti (2009) semakin tinggi jumlah anggota keluarga akan meningkatkan tekanan ekonomi keluarga.

Tekanan ekonomi sebagai salah satu konflik yang dialami keluarga diakibatkan oleh beberapa hal diantaranya akibat kehilangan pekerjaan, pendapatan yang rendah sehingga keluarga tidak mampu memenuhi kebutuhan hidupnya, tidak stabilnya aset dan hutang yang dimiliki (Tati, 2004), ketidakpastian sumber keuangan, ketidakstabilan kerja, dan atau tidak memadainya pendapatan untuk memenuhi kebutuhan atau keinginan (Fox \& Bartholomae, 2000). Menurut Higginbotham dan Felix (2009) tekanan ekonomi dari kurangnya sumber daya finansial meningkatkan resiko stres emosional, yang akan meningkatkan kesempatan konflik pernikahan dan ketidakstabilan pernikahan. Tekanan ekonomi akan memicu kekerasan, terutama pada pria, dan mengurangi kehangatan emosional dalam pernikahan, yang akan berkontribusi terhadap berkurangnya stabilitas. Kemampuan keluarga dalam mengatasi tekanan ekonominya dipengaruhi oleh cara keluarga mendefinisikan kondisi ekonomi keluarganya.

Hasil penelitian menunjukkan strategi koping pengurangan pengeluaran lebih tinggi dibandingkan strategi peningkatan pendapatan. Hal ini sejalan dengan penelitian Kabbaro, Hartoyo, dan Yulianti (2014) menunjukkan bahwa strategi koping yang selalu dilakukan keluarga diantaranya adalah dengan membeli pangan yang lebih murah, mengubah distribusi pangan, mengganti obat yang mahal dengan yang murah, memilih tempat berobat yang lebih murah, menangguhkan pengobatan, mengurangi pembelian pakaian, dan mengurangi pembelian perabot rumah tangga. Strategi koping pengurangan pengeluaran lebih mudah dilakukan keluarga dibandingkan strategi penambahan pendapatan. Strategi peningkatan penambahan membutuhkan sumber daya manusia dan jejaring sosial untuk meningkatkan sumber daya uang (Rosidah, Hartoyo, \& Muflikhati, 2012). Pengurangan pengeluaran (cutting back expenses) adalah strategi yang digunakan untuk merespon ketersediaan sumber daya yang lebih rendah melalui perubahan pola pengeluaran (Puspitawati, 2012). Menurut Johan, Muflikhati, dan Mukhi (2013) keluarga lebih sering melakukan strategi pengurangan pengeluaran dari pada peningkatan pendapatan ketika pendapatan sedang menurun. Selain itu, tinggi rendahnya keluarga melakukan strategi peningkatan pendapatan tergantung kepada ketersediaaan sumber daya yang dimiliki, ada tidaknya akses, dan kesempatan lapangan pekerjaan (Herawati, 2012).

Tabel 4 Pengaruh karakteristik keluarga, tekanan ekonomi, dan strategi koping terhadap ketahanan keluarga

\begin{tabular}{|c|c|c|c|}
\hline Variabel & $\begin{array}{l}\text { B } \\
\text { (Tidak Terstandardisasi) }\end{array}$ & $\begin{array}{l}\beta \\
\text { (Terstandardisasi) }\end{array}$ & Sig. \\
\hline Konstanta & 22,810 & & 0,165 \\
\hline Usia Menikah Istri & 1,203 & 0,697 & 0,089 \\
\hline Usia Menikah Suami & $-0,072$ & 0,536 & 0,894 \\
\hline Jumlah anggota keluarga & 4,877 & 1,793 & $0,009 * *$ \\
\hline Lama Menikah & 0,634 & 0,300 & $0,039^{*}$ \\
\hline Lama Pendidikan Istri & $-0,346$ & 0,723 & 0,634 \\
\hline Lama Pendidikan Suami & 0,605 & 0,505 & 0,235 \\
\hline Pendapatan per Kapita & $2,135 \times 10^{-6}$ & 0,000 & 0,442 \\
\hline Tekanan Ekonomi & $-0,295$ & 0,073 & $0,000^{* *}$ \\
\hline Strategi Koping & 0,048 & 0,143 & 0,737 \\
\hline $\mathrm{F}$ & 5,126 & & \\
\hline Sig & 0,000 & & \\
\hline Adj $R^{2}$ & 0,350 & & \\
\hline
\end{tabular}


Hasil penelitian menunjukkan persentase strategi koping ekonomi keluarga contoh berada pada kategori rendah. Aspek kesehatan merupakan aspek tertinggi yang dilakukan dalam strategi pengurangan pengeluaran. Pada dimensi peningkatan pendapatan aspek lainnya yaitu menjual aset untuk kebutuhan sehari-hari merupakan aspek tertinggi yang sering dilakukan keluarga. Lazarus dan Folkman (1984) keadaan stres yang dihadapi seseorang akan menimbulkan efek yang kurang menguntungkan baik secara fisiologis maupun psikologis. Pemilihan strategi koping berhubungan negatif dengan pendapatan per kapita, yang artinya semakin bertambah pendapatan per kapita keluarga maka akan menurunkan strategi koping yang dilakukan oleh keluarga (Kabbaro, Hartoyo, \& Yulianti 2014; Rosidah, Hartoyo, \& Muflikhati, 2012).

Ketahanan keluarga merupakan kemampuan keluarga dalam mengelola sumber daya dan masalah yang dihadapi untuk mencapai tujuan keluarga yaitu keluarga sejahtera. Hasil penelitian ini menunjukkan sebagian besar keluarga contoh berada pada kategori ketahanan fisik keluarga sedang. Menurut Walsh (2003) ketika keluarga, tetangga, dan teman yang mendukung bekerja sama untuk memeberikan dukungan sosial dan ekonomi, semua itu menjadi keuntungan untuk stabilitas sumber daya dalam unit keluarga dan pertetanggaan. Ketahanan fisik keluarga sangat berkaitan dengan kesejahteraan fisik keluarga dan kemampuan ekonomi keluarga (Sunarti, 2001). Hasil penelitian menunjukkan keluarga memiliki ketahanan sosial yang cukup baik. Menurut Jones et al. (2014) pernikahan muda tidak selamanya dipandang sebagai sebuah ancaman tetapi direncanakan untuk kesejahteraan dan ketahanan sosial. Menurut Sunarti (2001) keluarga akan memiliki ketahanan sosial yang baik apabila memiliki sumber daya non fisik yang baik, cara penanggulangan masalah yang baik untuk memenuhi kebutuhan sosialnya. Hasil penelitian menunjukkan lebih dari setengah keluarga contoh termasuk pada kategori ketahanan psikologis rendah. Menurut Sumbulah dan Jannah (2012) menikah diusia dini memiliki dampak psikologis sehingga kehidupan rumah tangganya tidak harmonis, sering bertengkar, dan akhirnya terjadi perceraian. Menurut Sunarti (2001) keluarga memiliki ketahanan psikologis yang baik keluarga memiliki kemampuan dalam mengelola emosi dan konsep diri yang baik dalam menghadapi masalah yang bersifat non fisik. Menurut Krysan et al. (1990) keluarga yang tahan memiliki ciri-ciri seperti adanya komunikasi yang baik dan efektif dalam keluarga, adanya dorongan dari anggota keluarga, memiliki komitmen, berorientasi dengan agama, mampu beradaptasi terhadap segala perubahan dalam keluarga, memiliki peran dan fungsi yang jelas, dan memiliki waktu berkumpul bersama keluarga.

Jumlah anggota keluarga berpengaruh positif terhadap ketahanan keluarga. Semakin banyak jumlah anggota keluarga maka ketahanan keluarga semakin meningkat. Hal ini berarti semakin banyak anggota keluarga maka keluarga akan semakin mampu mengelola masalah sosialnya, kondisi fisik ekonomi, dan kondisi psikologis keluarga sehingga berdampak meningkatnya ketahanan keluarga. Menurut Febriani (2013) menyebutkan transfer antar generasi menjadi jaring pengaman dalam memenuhi kebutuhan setiap anggota keluarga. Menurut Becker (1974) mengemukakan tentang motif altruism yang terjadi dalam sebuah hubungan keluarga yang menyatakan para anggota keluarga memiliki sifat kedermawanan terhadap anggota keluarga lainnya. Setiap kepala keluarga mengalokasikan sumber daya yang ada diantara anggota keluarga sehingga setiap anggota keluarga memiliki keadaan yang baik. Lama menikah berpengaruh positif terhadap ketahanan keluarga. Hal ini berarti semakin lama menikah pasangan suami istri telah memiliki kemampuan dan pengetahuan untuk memperoleh sumber daya ekonomi untuk mencukupi anggota keluarganya, mempunyai kemampuan yang baik dalam menyelesaikan permasalahan keluarga dan sosial, serta keluarga memiliki kemampuan mengelola emosi secara optimal sehingga ketahanan keluarga akan semakin meningkat. Semakin lama menikah maka keluarga akan memiliki kemampuan dan pengetahuan untuk mempertahankan keluarga, pengetahuan dan keterampilan akan mengoptimalkan keluarga dalam menjalankan manajemen keluarga sehingga tercapai ketahanan keluarga yang optimal (Iskandar, 2007).Tekanan ekonomi berpengaruh negatif dengan ketahanan keluarga total. Tekanan ekonomi yang dialami keluarga terkait dengan rendahnya manajemen sumber daya yang dilakukan keluarga. Manajemen sumber daya keluarga yang rendah akan menyebabkan kemampuan keluarga untuk bertahan menjadi berkurang. Pengoptimalan sumber daya dan kemampuan yang dimiliki menjadikan keluarga mampu untuk lebih tahan dalam menghadapi masalah dan tekanan yang terjadi. Kondisi inilah yang mendukung untuk mencapai suatu ketahanan 
keluarga.Hal ini sesuai dengan penelitian Okech et al. (2012) yang menyatakan semakin tinggi tekanan ekonomi keluarga maka ketahanan keluarga semakin rendah. Menurut Sunarti et al. (2003) ketahanan fisik dan psikologis keluarga akan tercapai apabila keluarga terhindar dari masalah ekonomi, masalah non ekonomi, terpenuhinya kebutuhan fisik dan psikologis yang baik.

\section{SIMPULAN DAN SARAN}

Rata-rata usia menikah istri yaitu 17 tahun dan rata-rata usia menikah suami yaitu 22 tahun. Rata-rata pendidikan suami istri adalah tamat SD. Keluarga merupakan keluarga kecil dengan rata-rata pendapatan per kapita per bulan sebesar Rp594 695. Secara keseluruhan tekanan ekonomi keluarga termasuk kategori sedang, strategi koping keluarga tergolong kategori rendah, ketahanan fisik, dan ketahanan sosial keluarga termasuk kategori sedang, sedangkan ketahanan psikologis keluarga tergolong kategori rendah. Ketahanan keluarga termasuk kategori sedang. Faktor yang memengaruhi ketahanan keluarga yaitu jumlah anggota keluarga, lama menikah, dan tekanan ekonomi keluarga.

Berdasarkan hasil penelitian, saran yang dapat diberikan diharapkan pemerintah semakin menggencarkan program Pendewasaan Usia Perkawinan (PUP) yang ditujukan kepada keluarga yang berada di perdesaan dengan cara menyosialisasikan program dan memberikan penyuluhan terkait program tersebut. Pemerintah semakin menggencarkan program wajib belajar 12 tahun agar tingkat pendidikan masyarakat perdesaan semakin tinggi. Selain itu pemerintah dan instansi terkait dapat melakukan pemberdayaan kepada keluarga miskin untuk meningkatkan pendapatan keuarga serta membuat ibu rumah tangga menjadi lebih produktif. Jumlah anggota keluarga diharapkan dioptimalkan dalam mengelola sumber daya keluarga sehingga tercapai ketahanan keluarga yang optimal. Semakin lama usia pernikahan diharapkan keluarga dapat melakukan strategi koping yang baik, penyesuaian keluarga yang baik sehingga ketahanan keluarga dapat tercapai secara optimal. Diharapkan keluarga memiliki tekanan ekonomi yang rendah dengan cara mengelola sumber daya yang dimiliki seoptimal mungkin sehingga ketahanan keluarga dapat menjadi lebih baik. Penelitian selanjutnya diharapkan melibatkan suami dalam wawancara dan melakukan kajian yang berhubungan dengan keluarga menikah usia muda seperti manajemen sumber daya keluarga, penyesuaian keluarga, keintiman dari pasangan suami istri, dan perkembangan anak dari pasangan muda.

\section{DAFTAR PUSTAKA}

[BKKBN] Badan Kependudukan dan Keluarga Berencana Nasional. (2010). Pendewasaanusia perkawinan dan hakhak reproduksibagi remaja Indonesia. Jakarta, ID: Ditrem BKKBN.

[BKKBN] Badan Koordinasi Keluarga Berencana Nasional (2012). Pernikahan muda pada beberapa provinsi di Indonesia: dampak overpopulation, akar masalah dan peran kelembagaan di daerah. Jakarta (ID): BKKBN.

[BPS] Badan Pusat Statistik. (2012). Jawa Barat dalam angka, Katalog BPS: Tingkat Kemiskinan Kabupaten dan Kota Bogor: hal 57. Jawa Barat, ID: BPS.

Becker, G. (1974). A theory of social interactions. The Journal of Political Economy, 82, 1063-1093.

Conger, R. D., Elder, G. H., Lorenz, F. O., Conger, K. J., Simons, R. L., Whitbeck, L. B., Huck, S., \& Melby, J. N. (1990). Linking economic hardship to marital quality and instability. Journal of Marriage and Family, 52(3), 643-656.

Conger, R. D., \& Elder, G. H. (1994). Families in troubled times: adapting to change in rural America. New York, USA: Aldine De Gruyter.

Dew, J. (2008). Debt change and marital satisfaction change in recently married couples. Family Relations, 57, 60-71.

Dew, J. P., \& Stewart, R. (2012). A financial issue, a relationship issue, or both examining the predictors of marital financial conflict. Journal of Financial Therapy, 3(1), 43-61.

Duvall, E. M. (1971). Family development: fourth edition. New York, USA: JB Lippincott Company.

Engerman, S. (1978). Economic perspectives on the life course. TK Harevan (editor). New York, USA: Academic Press.

Febriani, R. E. (2013). Banyak anak banyak rezeki, benarkah itu? Sebuah kajian penawaran tenaga kerja lanjut usia. Prosiding Seminar Nasional. Fakultas Ekonomi Uneversitas Negeri Padang. ISBN: 978-602-17129-1-7: 134-153. 
Firdaus \& Sunarti, E. (2009). Hubungan antara tekanan ekonomi dan mekanisme koping dengan kesejahteraan keluarga wanita pemetik teh. Jurnal IImu Keluarga dan Konsumen, 2(1), 21-31. Doi: http://dx.doi.org/10.24156/jikk.2009.2.1.2 1.

Fox, J. J., \& Bartholomae, S. (2000). Families and individuals coping with financial stress. In McKenry, P. C. \& Price, S. J (eds.), Families \& Change Coping With Stressful Events and Transitions, 2nd ed. (pp 250-271). California, USA: Sage Publication, Inc.

Ghalili, Z., Etemadi, O., Ahmadi, S. A., Fatehizaeh, M., \& Abedi, M. R. (2012). Marriage readiness criteria among young adults of Isfahan: A quantitative study. Interdiscplinary Journal of Contemporary Research Business, 4(4), 1076-1083.

Gunarsa, S. \& Gunarsa, Y. S. D. (2000). Asasasas psikologi keluarga idaman. Jakarta, ID: Gunung Mulia.

Hartoyo. (2009). Pemberdayaan ekonomi keluarga dalam rangka peningkatan ketahanan keluarga. Di dalam: Sunarti E, editor. Naskah akademis Pengembangan model ecovillage: pembangunan kawasan perdesaan serta peningkatan sumbangan pertanian bagi peningkatan kualitas hidup penduduk perdesaan. Bogor, ID: LPPM IPB.

Henly, J. R., Danziger, S. K., \& Offer, S. (2003). The contribution of social support to the economic status and daily coping of former and current welfare recipients.University of Chicago, USA: Chicago.

Herawati, T. (2012). Manajemen sumber daya keluarga dan ketahanan keluarga peserta program pemberdayaan masyarakat di pedesaan (kasus di Kabupaten Bogor) (Disertasi). Institut Pertanian Bogor, Bogor, Indonesia.

Higginbotham, B. J., \& Felix, D. (2009). Economic predictors of marital quality among newly remarried rural and urban couples. Family Science Review, 14(2), 18-30.

Iskandar. (2007). Analisis praktek manajemen sumber daya keluarga dan dampaknya terhadap kesejahteraan keluarga di kabupaten dan Kota Bogor (Disertasi). Institut Pertanian Bogor, Bogor, Indonesia.
Jain, G., Bisen, V., Singh, S. K., \& Jain, P. (2011). Early marriage of girl as a barrier to their education. International Journal of Advanced Engineering Technology, 2(3), 193-198.

Jisun, T. F. (2016). Early marriage of woman: the case of Bangladesh. World Journal of Social Sciences, 6(2), 51-61.

Johan, I. R., Muflikhati, I., \& Mukhti, D. S. (2013). Gaya hidup, manajemen keuangan, strategi koping, dan kesejahteraan keluarga nelayan. Jurnal IImu Keluarga dan Konsumen, 6 (1), 3038. Doi: http://dx.doi.org/10.24156/jikk.2013.6.1.3 0 .

Jones, N., Tefera, B., Stephenson, J., Gupta, T., Pereznueto, P., Emire, G., Gebre, B., \& Gezhegne, K. (2014). Early marriage and education: the complex role of social norms in shaping Ethiopian adolescent girls' lives. Country Report: Shaping policy for development, 1-103.

Kabbaro, H, Hartoyo, \& Yuliati, L. N. (2014). Modal sosial, strategi koping, dan kesejahteraan objektif keluarga dengan perempuan sebagai kepala keluarga. Jurnal IImu Keluarga dan Konsumen, 7 (3), 164-173. Doi: http://dx.doi.org/10.24156/jikk.2014.7.3. 164.

Krysan, M., Moore, K. A., \& Zill, N. (1990). Research on succesful families. A report on a conference sposored by the office of the assistant secretary for planning and evaluation. US Departement of health and human services. 1-23.

Landung J., Thaha R., \& Adullah A. Z. (2009). Studi kasus pernikahan dini pada masyarakat Kecamatan Sanggalangi Kabupaten Tana Toraja. Jurnal MKMI, 5(4), 89-94.

Lazarus, R. S., \& Folkman, S. (1984). Stress, appraisal, and coping. New York, USA: Springer.

Mistry, R. S., Lowe, E. D., Benner, A. D., \& Chien, N. (2008). Expanding the family economic stress model: Insight from a mixed-methods approach. Journal of Marriage and Family, 70(1), 196-209.

Okech, D., Howard, W. J., Mauldin, T., Mimura, Y., \& Kim, J. (2012). Effect of economic pressure on resilience and strengths of indivisuals living in extreme poverty. Journal of Poverty, 16, 429-446. 
Puspitawati, H. (2012). Gender dan keluarga: konsep dan realita di Indonesia. Bogor, ID: IPB Press.

Rafidah, Emilia O., \& Wahyuni B. (2009). Faktor-faktor yang berhubungan dengan pernikahan usia dini di kabupaten Purwarejo Jawa tengah. Berita Kedokteran Masyarakat, 25(2), 51-58.

Rosidah, U., Hartoyo, \& Muflikhati, I. (2012). Kajian strategi koping dan perilaku investasi anak pada keluarga buruh pemetik melati gambir. Jurnal IImu Keluarga dan Konsumen, 5(1), 77-87. Doi:

http://dx.doi.org/10.24156/jikk.2012.5.1.7 7.

Sah, R., Gaurav, K., Baral, D., Subedi, L., Jha, N., \& Porkharel, P. (2014). Factors associated with age marriagein Dhankuta Municipality, Nepal. Nepal Journal of Medical Sciences, 3(1), 26-30.

Sudarto, A. (2014). Studi deskriptif kepuasan perkawinan pada perempuan yang menikah muda. Jurnal IImiah Mahasiswa Universitas Surabaya, 3(1), 1-15.

Sumbulah, U., \& Jannah, F. (2012). Pernikahan dini dan implikasinya terhadap kehidupan keluarga pada masyarakat Madura (perspektif hukum dan gender). Jurnal Kesetaraan dan Keadilan Gender, 7(1), 83-101.
Sunarti, E. (2001). Studi ketahanan keluarga dan ukurannya: telaah kasus pengaruhnya terhadap kualitas kehamilan (Disertasi). Institut Pertanian Bogor, Bogor, Indonesia.

Hidayat, S., Megawangi, R., Hardinsyah, Saefuddin, A., \& Husaini. (2003). Perumusan ukuran ketahanan keluarga.Media Gizi dan Keluarga, 27(1), 1-11.

Tati. (2004). Pengaruh tekanan ekonomi keluarga, dukungan sosial dan kualitas perkawinan terhadap pengasuhan anak (Tesis). Institut Pertanian Bogor, Bogor, Indonesia.

Tsania, N., Sunarti, E., \& Krisnatuti, D. (2015). Karakteristik setelah berkeluarga, kesiapan menikah istri dan perkembangan anak usia 3-5 tahun. Jurnal IImu Keluarga dan Konsumen, 8 (1), 28-37. Doi: http://dx.doi.org/10.24156/jikk.2015.8.1.2 8

Walsh, F. (2003). Family resilience: a framework for clinical practice. Family Process, 42(1), 1-19.

Yadollahi, M., Paim, L., Othman, M., \&Suandi T. (2009). Factors affecting family status. European Journal of Scientific Research, 37(1), 94-109. 